\title{
Sensitivity and resistance of the microbiota of reproductive organs and mammary gland of cows to anti-microbial agents in cases of inflammation
}

\author{
N.A. Bezborodova, O.V. Sokolova, I.A. Shkuratova, M.V. Ryaposova, \\ Ya.Yu. Lysova, M.N. Isakova, V.V. Kozhukhovskaya \\ Ural Federal Agrarian Scientific Research Centre \\ Russian Federation
}

Received: April 1, 2020. Revised: May 9, 2020. Accepted: May 29, 2020.

Published: June 8, 2020.

\begin{abstract}
This paper contains the results of complex microbiological studies (culture method, real-time PCR) of biological material from cows affected by inflammatory diseases of reproductive organs and mammary gland. Milk microbiota with underlying subclinical mastitis was represented by pathogenic (S. aureus, enteropathogenic $E$. coli), opportunistic bacteria (Staphylococcus spp., E. coli, E. faecium, Streptococcus spp., S. agalactiae, P. aeruginosa) and yeast-like fungi of Candida spp. in association. Combined infectious and inflammatory diseases of genital tract and mammary gland in cows resulted in the same types of microorganisms in microflora composition, which confirms information obtained by other researchers on associated microbiota during inflammatory processes. $S$. aureus, $P$. aeruginosa, E. coli, E. faecium, E. faecalis, $S$. epidermidis, S. saprophyticus, Bacillus spp., and yeast-like fungi of Candida spp. were obtained from milk samples from cows with acute clinical mastitis and in vaginal washes from cows with acute postpartum endometritis. In the course of defining the sensitivity to antibiotics and identifying genes of antimicrobial resistance, multidrug resistance was established in most part of obtained strains, which should be taken into account when planning treatment measures.
\end{abstract}

Keywords-Microbiota, mastitis, acute postpartum endometritis, vaginitis, antibiotic resistance.

\section{INTRODUCTION}

$\mathrm{I}$ Nflammatory diseases of reproductive organs and mammary gland in cows are one of the main reasons for reduced reproductive function and animal productivity [1], [2]. Mastitis causes the greatest economic damage due to a decrease in milk yield and quality, as well as premature culling, diseases of newborn calves and costs of treating sick animals. Predisposing causes for mastitis in cows are the following: genetic predisposition, conditions of keeping and feeding animals, individual characteristics of an animal, immune status, result of preventive measures [3]. Microbial factors are considered to be crucial in the etiology of mastitis. Researchers mention that the main infectious causative agents of mastitis in cows in the world are M. bovis, coccus bacteria, mainly Staphylococcus spp., in particular, Staphylococcus aureus and Streptococcus spp., also including Streptococcus agalactiae, Streptococcus dysgalactiae, Streptococcus uberis, in associations and in pure culture. Enterobacter spp., Escherichia coli, Klebsiella spp., Pseudomonas spp., Arcanobacterium are also often found in mastitis [4] [9]. Cases of sporadic acute mastitis with $C$. perfringens as a causative agent are also described in literature [10].

According to the literature, there is a close vascular and functional relation between mammary gland and genital system in cows, which also determines associated development of pathological processes in these organs. Many researchers registered that in bacteriological studies of biomaterials taken from mammary gland and genital organs of cows, the same pathogenic microflora was obtained and identified. Macías Alonso M., López Salazar J.C., Osegueda Robles S. in their study [11] established an etiological association between diseases of mother cows, streptococcal mastitis, endometritis, and polyarthritis in newborn calves.

Development of mastitis and endometritis in cows depends not only on pathogenic, but also on opportunistic (potentially pathogenic) microflora, which is found in association of microorganisms, and this fact is considered by a number of authors as a result of the uncontrolled usage of antimicrobial drugs in animal husbandry. It is known that antibiotic therapy affects not only pathogenic, but also normal flora resulting in dysbiosis and new antibiotic-resistant strains. Veterinary specialists currently note multiple antimicrobial resistance of microorganisms obtained from animals with different course 
of endometritis and mastitis, which is one of the factors for transition of acute forms to chronic and subclinical ones [12][15].

Screening for mastitis, metritis and vaginitis includes routine bacteriological test and PCR. These methods are mutually complementary and provide great opportunities in diagnostics and typing of pathogens, followed by defining the level of sensitivity to antibiotics, as well as identification of antimicrobial resistance genes. In practical veterinary medicine, it allows to quickly decide on the appointment of an antimicrobial drug and to perform effective treatment and preventive measures. In addition, such screening underlies the strategy for preventing spreading antimicrobial resistance of microorganisms [16]-[18].

The goal of this study was to analyze sensitivity and resistance of pathogenic and opportunistic microorganisms obtained from mammary secret and vaginal washes from cows with inflammatory diseases of reproductive organs and mammary gland to antimicrobial drugs.

\section{MATERIALS AND METHODS}

The reported study was funded by RFBR and Sverdlovsk oblast, project number 20-416-660004, and was performed at the Federal State Budgetary Research Institution "Ural Federal Agrarian Scientific Research Center" of the Ural Branch of the Russian Academy of Sciences.

The object included 46 samples of milk from cows with subclinical mastitis, 20 samples of milk and vaginal washes from cows with clinical mastitis and acute postpartum endometritis, 20 samples of milk and vaginal washes from cows with subclinical mastitis and signs of vaginitis. Biomaterial samples were used for growth of microorganisms to define sensitivity of obtained bacterial strains to antibiotics and for real-time PCR to define their resistance to the groups of antimicrobial agents.

Microbiological studies of biological material were carried out according to common methods. In our study, we used enrichment and differential media (Nutrient Broth, differential culture media No. 10 for the identification of Staphylococcus aureus, Cetrimide Agar; Endo agar, Bismuth sulfite agar, Enterococcus agar, Czapek medium, EMB Agar, Levine (M022), Salmonella Shigella (SS) Agar- Composition, Sabouraud agar, hektoen enteric agar, Columbia agar, XLD agar).

Bacteria were identified by the method of passage in Hiss medium (Gissa medium) with glucose, lactose, sucrose, maltose, mannitol, arabinose, dulcite, xylose, mannose, rhamnose. These nutrient media are used at the stage of isolation and identification of microorganisms of the Enterobacteriaceae family by the fermentation of one of the carbohydrates. For bacteria identification we used gram stain technique. Additionally, we used biochemical plates for enterobacteria differentiation - PBDE (identification by 20 diagnostic criteria: utilization of sodium citrate, utilization of sodium malonate, utilization of sodium citrate with glucose, presence of lysine decarboxylase, presence of arginine dehydrolase, utilization of ornithine decarboxylase, presence of phenalalanine deaminase, formation of indole, formation of acetyl methyl carbinol, presence of urease, formation of hydrogen sulfide, utilization of glucose, $\beta$-galactose, lactose, $\beta$-galactose mannitol, sucrose utilization, inositol utilization, sorbitol utilization, arabinose utilization, maltose utilization) by "Diagnosticheskiye Systemy" LLC Research and Production Association, Russia. Pathogenicity of obtained strains was determined by biological test in laboratory animals (white mice). Preliminary identification of S.aureus was based on colony morphology, gram staining and rabbit plasma coagulation. Antibiotic resistance in all obtained bacterial cultures was defined using disk-diffusion agar method. We used standard commercial disks with known active substance (ampicillin $-10 \mu \mathrm{g}$, amoxicillin $-20 \mu \mathrm{g}$, doxycycline $-30 \mu \mathrm{g}$, levomycetin $-30 \mu \mathrm{g}$, ofloxacin $-5 \mu \mathrm{g}$, rifampicin $-5 \mu \mathrm{g}$, ceftriaxone $-30 \mu \mathrm{g}$, ciprofloxacin $-5 \mu \mathrm{g}$, meropenem -10 $\mu \mathrm{g}$, tobramycin $-10 \mu \mathrm{g})$.

During PCR, the Diatom DNA Prep 200 DNA isolation kit (IzoGen LLC, Russia) was used. For defining specific DNA region of bacterial pathogens (Staphylococcus aureus, Streptococcus agalactiae, E. coli, Staphylococcus spp., Proteus spp., E. faecium, E. faecalis) in samples, we used a reagent kit for "VETSKRIN. Streptopol-V", "VETSKRIN. Stafipol", "VETSKRIN. Kolipol", and "VETSKRIN. Streptopol" test systems (Russia). To determine the resistance to antimicrobial agents, we used reagent kits by "NPF Litekh" LLC (Russia): resistance of Staphylococcus aureus to $2^{\text {nd }}$ generation cephalosporins (detection of the MecA gene); resistance of Enterobacteriaceae family to penicillins with beta lactamase inhibitors and $3^{\text {rd }}$ and $4^{\text {th }}$ generation cephalosporins (detection of the blaDHA gene); resistance of Enterobacteriaceae and Pseudomonas to carbapenems (detection of VIM genes); resistance of Staphylococcus spp. and Streptococcus spp. to $1^{\text {st }}$ generation macrolides (detection of the ErmB gene); resistance of Enterobacteriaceae family to $1^{\text {st }}$ generation cephalosporins and fluoroquinolones (detection of the STX-M gene) - "Vetskrin". PCR tests were performed in real time using a Rotor-Gene 3000 analyzer (Australia).

\section{RESULTS}

In all 46 milk samples from cows with subclinical mastitis, the DNA of bacteria of the Staphylococcus spp. group (S.epidermidis, $S$ saprophyticum, S.haemolyticus) was detected by PCR. S. aureus DNA was isolated in 4 samples (8.7\%), E. coli DNA - in 14 samples $(30.4 \%)$. In $13.1 \%$ of milk samples, DNA of $S$. agalactiae was found. In $7(35 \%)$ samples containing DNA Staphylococcus spp. ErmB resistance genes to 1 st generation macrolides were identified; $50.0 \%$ isolates $S$. aureus had a resistance gene (MecA) to 2 nd generation cephalosporins.

E. coli had no mutation genes for $1^{\text {st }}$ generation cephalosporins but had blaDHA in 13 (92.8\%) samples which causes resistance to protected penicillins and cephalosporins 3 and 4 generations.

In a culture-based study, cultures of S. aureus, E. faecium, bacteria of Streptococcus spp. group were isolated from all biological samples of milk from cows with subclinical mastitis; $S$. epidermidis was found in $17.4 \%$ of samples; $P$. aeruginosa and yeast-like fungi of Candida spp. were found 
in $8.7 \%$ of milk samples. All S. aureus isolates were a positive plasma coagulation.

As a result of this study, multidrug resistance of $S$. aureus and $E$. faecium to amoxicillin, levomycetin, ampicillin, and doxycycline was defined. Isolated $P$. aeruginosa strains were not sensitive to ampicillin and doxycycline. Opportunistic $S$. epidermidis strain was resistant to meropenem, ampicillin, doxycycline and levomycetin. In the course of biological tests in laboratory animals, enteropathogenic types of $E$. coli were revealed in $8.7 \%$ of milk samples. It is known that such bacterial agents lead to outbreaks of enteritis and gastroenteritis in young farm animals. Enteropathogenic $E$. coli was sensitive to ciprofloxacin and ofloxacin, but resistant to all other selected antibiotics.

PCR test of milk samples from cows with clinical mastitis and acute postpartum endometritis revealed genomes of bacteria of Staphylococcus spp group (S.epidermidis, S. saprophyticum, S.haemolyticus), E. coli, in $3(15.0 \%)$ samples single DNA of $S$. aureus. In $7(35.0 \%)$ isolates E. coli were detected blaDHA, which determine resistance to protected penicillins and cephalosporins of the 3rd and 4th generations. In bacteria of Staphylococcus spp. group, mutation genes to $1^{\text {st }}$ generation macrolides (ErmB) were found.

E. faecium, E. faecalis, S. aureus, non-pathogenic E. coli bacteria were obtained from milk samples from cows with clinical mastitis using culture methods; 2 (10.0\%) samples contained $P$. aeruginosa culture and yeast-like fungi of Candida spp. All obtained cultures of $S$. aureus had a positive reaction during plasma coagulation.

Antibiotic resistance test revealed that bacterial cultures of E. faecium and E. faecalis were not sensitive to amoxicillin. E. coli, S. aureus, $P$. aeruginosa in all samples showed multiple antibiotic resistance (doxycycline, tobramycin, ceftriaxone).

All vaginal swab samples from cows with acute postpartum endometritis contained DNA of E. coli, having the STX-M resistance gene in $40.0 \%$ of samples, the VIM gene in $5 \%$ of samples, and blaDHA in $10 \%$ of samples. In 2 samples of $E$. coli, two resistance genes (STX-M + blaDHA and STX-M + VIM) were detected in each.

Microbiological tests revealed bacterial cultures of $P$. aeruginosa, E. faecium, E. faecalis, E. coli, S. epidermidis in all biological samples. Bacillus spp., S. saprophyticus, yeastlike fungi of Candida spp. were occasionally cultivated in 5 samples. Obtained microflora of pathogenic and opportunistic bacteria showed resistance to several antibiotics (tobramycin, levomycetin, meropenem).

Real-time PCR of clinical samples from cows with subclinical mastitis and vaginitis revealed DNA of bacteria of Proteus spp. Group in $40.0 \%$ of samples, in $50.0 \%$ samples E. coli and in all milk samples - E. faecalis. In vaginal washes of the same cows, genomes of Proteus spp. bacteria and E. coli were found. Simultaneously conducted bacteriological test showed cultures of E. faecalis, E. coli in all samples of vaginal washes and in milk; $S$. aureus and $P$. aeruginosa in $20 \%$ of samples. All S. aureus isolates were a positive plasma coagulation.

PCR diagnostics of antibiotic resistance revealed resistance gene STX-M to cephalosporins and carbapenems of the first line in selected specific DNA regions of $3(37.5 \%)$ isolates Proteus spp. and in $2(20.0 \%)$ isolates E. coli. In 1 isolate $E$. faecalis revealed resistance gene to $1^{\text {st }}$ line macrolides (ErmB). Isolated microorganisms were not sensitive to antibiotics (ampicillin, amoxicillin, doxycycline, levomycetin, ofloxacin, rifampicin, meropenem, tobramycin), which was confirmed by PCR results.

As a result of studies of clinical samples taken from animals with inflammatory diseases of reproductive organs and mammary gland, all obtained cultures of $S$. aureus had a positive reaction during plasma coagulation. Several mutation genes were found in DNA of $E$. coli that were responsible for resistance to penicillins, $1^{\text {st }}$ and $2^{\text {nd }}$ generation cephalosporins, and $1^{\text {st }}$ generation carbapenems $($ Table 1,2$)$

Table 1. Results of test for antibiotic sensitivity and resistance of microorganisms obtained from mammary secret of cows with mastitis

\begin{tabular}{|c|c|c|}
\hline \multirow{2}{*}{$\begin{array}{l}\text { Obtained } \\
\text { pathogens }\end{array}$} & \multicolumn{2}{|c|}{ Resistance to antimicrobial drugs } \\
\hline & $\begin{array}{l}\text { Disk-diffusion } \\
\text { agar method }\end{array}$ & Real-time PCR \\
\hline $\begin{array}{l}\text { Staphylococcu } \\
\text { s spp. }\end{array}$ & - & $\begin{array}{c}1^{\text {st }} \text { generation } \\
\text { macrolides } \\
(\text { ErmB }, \mathrm{n}=67.5 \%)\end{array}$ \\
\hline S. aureus & $\begin{array}{l}\text { ampicillin, } \\
\text { amoxicillin, } \\
\text { doxycycline, } \\
\text { levomycetin, } \\
\text { ceftriaxone, } \\
\text { tobramycin }\end{array}$ & $\begin{array}{c}1^{\text {st }} \text { generation } \\
\text { cephalosporins } \\
(\mathrm{MecA}, \mathrm{n}=50.0 \%)\end{array}$ \\
\hline S. epidermidis. & $\begin{array}{l}\text { ampicillin, } \\
\text { doxycycline, } \\
\text { levomycetin, } \\
\text { meropenem }\end{array}$ & $\begin{array}{l}\text { no resistance genes } \\
\text { found }\end{array}$ \\
\hline $\begin{array}{c}\text { Streptococcus } \\
\text { spp. }\end{array}$ & $2+2=$ & $\begin{array}{l}\text { no resistance genes } \\
\text { found }\end{array}$ \\
\hline S. agalactiae & - & $\begin{array}{l}\text { no resistance genes } \\
\text { found }\end{array}$ \\
\hline E. faecium & $\begin{array}{l}\text { ampicillin, } \\
\text { amoxicillin, } \\
\text { doxycycline, } \\
\text { levomycetin }\end{array}$ & $\begin{array}{l}\text { no resistance genes } \\
\text { found }\end{array}$ \\
\hline E. faecalis & amoxicillin & $\begin{array}{l}1^{\text {st }} \text { line macrolides } \\
(\text { ErmB }, \mathrm{n}=5.0 \%)\end{array}$ \\
\hline E. coli & $\begin{array}{l}\text { ampicillin, } \\
\text { amoxicillin, } \\
\text { doxycycline, } \\
\text { levomycetin, } \\
\text { ceftriaxone, } \\
\text { tobramycin }\end{array}$ & $\begin{array}{c}\text { Penicillins, } 1^{\text {st }}, 2^{\text {nd }} \text {, } \\
3^{\text {rd }} \text { and } 4^{\text {th }} \text { generation } \\
\text { cephalosporins } \\
\text { (blaDHA, } n=37.0 \%) \\
1 \text { st generation } \\
\text { cephalosporins } \\
(\mathrm{STX}-\mathrm{M}, \mathrm{n}=3.7 \%)\end{array}$ \\
\hline Proteus spp. & $\begin{array}{l}\text { ampicillin, } \\
\text { amoxicillin, } \\
\text { doxycycline, } \\
\text { levomycetin, } \\
\text { ofloxacin, } \\
\text { rifampicin, } \\
\text { ceftriaxone, }\end{array}$ & $\begin{array}{c}\text { 1st generation } \\
\text { cephalosporins } \\
(\mathrm{STX}-\mathrm{M}, \mathrm{n}=40.0 \%)\end{array}$ \\
\hline
\end{tabular}




\begin{tabular}{ccc}
\hline & $\begin{array}{c}\text { ciprofloxacin, } \\
\text { meropenem, } \\
\text { tobramycin }\end{array}$ & \\
\hline P. aeruginosa & $\begin{array}{c}\text { ampicillin, } \\
\text { doxycycline, } \\
\text { ceftriaxone, } \\
\text { tobramycin }\end{array}$ & no resistance genes \\
& & \\
&
\end{tabular}

Table 2. Results of test for antibiotic sensitivity and resistance of microorganisms obtained from cows with inflammatory diseases of reproductive system

\begin{tabular}{|c|c|c|}
\hline \multirow[t]{2}{*}{ Obtained agents } & \multicolumn{2}{|c|}{ Resistance to antimicrobial drugs } \\
\hline & $\begin{array}{l}\text { Disk-diffusion } \\
\text { agar method }\end{array}$ & \\
\hline E. coli & $\begin{array}{l}\text { ampicillin, } \\
\text { amoxicillin, } \\
\text { doxycycline, } \\
\text { levomycetin, } \\
\text { ofloxacin, } \\
\text { rifampicin, } \\
\text { meropenem, } \\
\text { tobramycin }\end{array}$ & $\begin{array}{c}1^{\text {st }} \text { generation } \\
\text { cephalosporins } \\
(\mathrm{STX}-\mathrm{M}, \mathrm{n}= \\
33.3 \%) \\
1^{\text {st }} \text { generation } \\
\text { carbapenems } \\
(\mathrm{VIM}, \mathrm{n}=3.3 \%) \\
\text { penicillins and } 3^{\text {st }} \\
\text { and } 4^{\text {nd }} \text { generation } \\
\text { cephalosporins } \\
\text { (blaDHA, n= } \\
6.6 \%) \\
(\mathrm{STX}-\mathrm{M}+ \\
\text { blaDHA=3.3\%) } \\
\text { (STX-M + VIM, } \\
\text { n=3.3\%) }\end{array}$ \\
\hline P. aeruginosa & $\begin{array}{l}\text { tobramycin, } \\
\text { levomycetin, } \\
\text { meropenem }\end{array}$ & 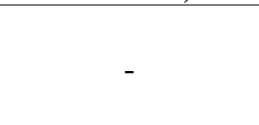 \\
\hline Bacillus spp. & $\begin{array}{l}\text { tobramycin, } \\
\text { levomycetin, } \\
\text { meropenem }\end{array}$ & - \\
\hline E. faecalis & $\begin{array}{l}\text { ampicillin, } \\
\text { amoxicillin, } \\
\text { doxycycline, } \\
\text { levomycetin, } \\
\text { ofloxacin, } \\
\text { rifampicin, } \\
\text { meropenem, } \\
\text { tobramycin }\end{array}$ & - \\
\hline E. faecium & $\begin{array}{l}\text { amoxicillin } \\
\text { tobramycin, } \\
\text { levomycetin, } \\
\text { meropenem }\end{array}$ & - \\
\hline Proteus spp. & - & $\begin{array}{c}1^{\text {st }} \text { generation } \\
\text { cephalosporins } \\
(\mathrm{STX}-\mathrm{M}, \mathrm{n}= \\
37.5)\end{array}$ \\
\hline S. aureus & $\begin{array}{l}\text { ampicillin, } \\
\text { amoxicillin, } \\
\text { doxycycline, }\end{array}$ & - \\
\hline
\end{tabular}

\begin{tabular}{ccc}
\hline & $\begin{array}{c}\text { levomycetin, } \\
\text { ofloxacin, } \\
\text { rifampicin, } \\
\text { meropenem, } \\
\text { tobramycin }\end{array}$ & \\
\hline S. epidermidis & $\begin{array}{c}\text { tobramycin, } \\
\text { levomycetin, } \\
\text { meropenem }\end{array}$ & - \\
\hline S. & $\begin{array}{c}\text { tobramycin, } \\
\text { levomycetin, } \\
\text { meropenem }\end{array}$ & - \\
\hline Staphylococcus & - \\
spp. & & - \\
\hline
\end{tabular}

\section{DISCUSSION}

Modern research confirms that different body sites or body fluids are now considered to host a complex microbial community with great diversity [19]. At the same time, researchers point to the relationship of the microbiota of the mammary gland and the genital organs of cows. Using the culture method and PCR, we studied the composition of the prevailing microorganisms in milk and vaginal swabs in three groups of cows: 1 - cows with subclinical mastitis, 2 - cows with clinical mastitis and acute postpartum endometritis, 3 cows with subclinical mastitis and vaginitis. In addition, we determined the resistance of bacteria to antibiotics by the disk diffusion method and in real-time PCR.

After conducting microbiological and PCR tests, we found that microbiota in milk samples from cows with subclinical mastitis was represented by pathogenic bacteria (enteropathogenic E. coli, S. aureus positive during plasma coagulation), opportunistic bacteria (Staphylococcus spp ., Streptococcus spp., E. faecium, S. agalactiae, P. aeruginosa, E. coli, Proteus spp.), and yeast-like fungi of Candida spp. in association. Multiple resistance of microorganisms to antibiotics (ampicillin, amoxicillin, doxycycline, levomycetin, meropenem) was revealed. E. coli culture was sensitive to ciprofloxacin and ofloxacin but was resistant to broadspectrum tetracyclines and penicillins. Moreover, mutant genes to $1^{\text {st }}$ generation macrolides, as well as to penicillins with beta lactamase inhibitors and $2^{\text {nd }}, 3^{\text {rd }}$ and $4^{\text {th }}$ generation cephalosporins were found in the genomes of obtained bacteria.

In milk samples from cows with clinical mastitis and in vaginal washes from cows with acute postpartum endometritis, polymicrobial communities of pathogenic and opportunistic bacteria were found. Opportunistic microflora, regardless of the course of endometritis and mastitis in cows, included E. coli, E. faecium, E. faecalis, S. epidermidis, S. saprophyticus, Bacillus spp., Proteus spp., yeast-like fungi of Candida spp.

E. faecium, E. faecalis were not sensitive to amoxicillin. Multiple antibiotic resistance of $E$. coli, $S$. aureus, $P$. aeruginosa was established; microorganisms showed resistance to doxycycline, tobramycin, ceftriaxone, levomycetin and meropenem.

Microbiota of vaginal washes and milk from cows with subclinical mastitis and vaginitis was represented by a 
combination of opportunistic microorganisms: Proteus spp., E. coli and E. faecalis, P. aeruginosa. Bacteria of Proteus spp. group and $E$. coli had resistance genes to cephalosporins and carbapenems of $1^{\text {st }}$ line, E. faecalis was resistant to $1^{\text {st }}$ line macrolides.

Moreover, obtained microbiota had no sensitivity to a number of chemotherapeutic agents. Herewith, obtained microflora was proven to have resistance genes to several groups of antimicrobial drugs. Therefore, simultaneous tests for antibiotic resistance by disk-diffusion agar method and real-time PCR allows obtaining additional results and getting a more complete information on existing drug resistance.

Resistant strains of microorganisms arise when the genome of bacterial cell changes as a result of spontaneous mutations [20]. We associate resistance development rate and intensity with the species and even with the strain of pathogen.

Our data are consistent with those of other researchers, which also isolated from milk of cows with inflammation of the mammary gland typical contagious bacteria and environmental bacteria [21], [22]. At the same time, our studies revealed that the composition of microflora in cows with infectious and inflammatory diseases of reproductive system and mammary gland was represented by the same types of microorganisms what confirms the information obtained by other researchers about the close association of microbiota in the development of inflammatory processes.

A comparative study of the species diversity and resistance of microorganisms of the reproductive tract and mammary gland to antibiotics, taking into account the environmental and regional characteristics of the Ural region of Russia, will expand the data on the spread of antibiotic resistance of microorganisms obtained by other researchers. Based on this, an integrated approach to the treatment and prevention of diseases of the breast and reproductive organs will be formed, which will improve the quality and safety of milk

\section{CONCLUSIONS}

1. Studies have shown that polymicrobial associations of pathogenic and opportunistic bacteria are involved in the development of mastitis and endometritis in cows.

2. The composition of microflora in mastitis and inflammation of the reproductive tract is represented by the same types of microorganisms.

3. Ciprofloxacin and ofloxacin were characterized with the highest antibacterial activity; doxycycline, tobramycin, levomycetin, amoxicillin and meropenem had the lowest one.

4. Resistance to antibacterial drugs was most often observed in E. coli.

5. Results of our study demonstrated high antimicrobial resistance of the studied isolates of the microbiota of reproductive system and mammary gland in cows with inflammation and confirmed the development of multidrug resistance what should be taken into account when performing treatment. This will help in the selection of therapeutic regimens.

\section{References}

[1] M. Ryaposova, I. Shkuratova, D. Kadochnikov, M. Tarasenko, Microbial profile of mastitis and endometritis in cows in breeding farms of the Ural Region, Veterinary of Farm Animals. no. 4, pp. 37-39, 2016.

[2] L. Li, X. Chen, Z. Chen, Identification of Key Candidate Genes in Dairy Cow in Response to Escherichia coli Mastitis by Bioinformatical Analysis. Front Genet. 2019 Dec 6;10:1251, doi: 10.3389/fgene.2019.01251. eCollection, 2019.

[3] M.N. Isakova, M.V. Ryaposova, N.A. Bezborodova, O.A. Britsina, Microbiological background of mammary inflammation in highly productive cows, Russian Journal: Problems of Veterinary Sanitation, Hygiene and Ecology, no. 2 (22), pp. 63-67, 2017

[4] D.N. Masyuk, S.G. Kolyada, A.V. Kokarev, N.Yu. Neverkovets, Present-day ideas about laboratory diagnosis of mastitis in cows, Feed and Facts. no. 1-2. P.44-47, 2017.

[5] L.V. Shamsieva, Veterinary and hygienic justification of the productive qualities of cows associated with genetic factors. Dissertation for a degree of Candidate of Biological Sciences, Kazan, pp. 135, 2018.

[6] N.A. Bezborodova, O.V Sokolova, M.V. Ryaposova, M.N. Isakova, Genetic markers of antibiotic resistance of pathogenic bacteria in the milk of cows and goats, Digital Agriculture - Development Strategy. Proceedings of International Scientific and Practical Conference (ISPC 2019). Advances in Intelligent Systems Research Series pp. 44-48, 2019. DOI: 10.5281/zenodo.3518721.

[7] M.N. Isakova, M.V. Ryaposova, N.A. Bezborodova, Evaluation of microbiological risk factors associated with mastitis in cows/ Reproduction in Domestic Animals. vol. 53. no.22. pp. 147-148, 2018.

[8] P. Isaac, L.P. Bohl, M.L. Breser, M.S. Orellano, A. Conesa, M.A. Ferrero, C. Porporatto, Commensal coagulase-negative Staphylococcus from the udder of healthy cows inhibits biofilm formation of mastitis-related pathogens. Vet Microbiol. 2017 Aug; 207:259-266. doi: 10.1016/j.vetmic.2017.05.025. Epub 2017 Jun 27.

[9] S. Özdemir, S. Altun, Genome-wide analysis of mRNAs and IncRNAs in Mycoplasma bovis infected and noninfected bovine mammary gland tissues. Mol Cell Probes. 2020 Jan 20:101512. doi: 10.1016/j.mcp.2020.101512.

[10] A.M. Johnston, A successfully treated case of mastitis in the bovine associated with Clostridium perfringens type A. Vet Rec. 1986 Jun 28; 118(26):728-9.

[11] M. Macías Alonso, J.C. López Salazar, S. Osegueda Robles, F. Ledezma García, J.G Marrero, In vitro antimicrobial activity of mexican plants on bovine mastitis bacteria: Preliminary studies. Bioscience Journal. vol. 36. Issue 1. Pp. 183-190, January-February 2020.

[12] V.V. Demkin, Species diversity of lactobacilli of vaginal microbiota: how to observe, Molecular Genetics, Microbiology and Virology, 36(3), pp. 3-12, 2018. DOI: 10.17116/molgen2018360313.

[13] A Zecconi, F. dell'Orco, N. Rizzi, D. Vairani, M. Cipolla, P. Pozzi, L. Zanini, Cross-sectional study on the 
prevalence of contagious pathogens in bulk tank milk and their effects on somatic cell counts and milk yield. Italian Journal of Animal Science. vol. 19, Issue 1, 14 December 2020 , Pages 66-74. doi.org/10.1080/1828051X.2019.1693282.

[14] M. Nüesch-Inderbinen, N. Käppeli, M. Morach, C. Eicher, S. Corti, R. Stephan, Molecular types, virulence profiles and antimicrobial resistance of Escherichia coli causing bovine mastitis. Vet Rec Open. 6(1), e000369, 2019 Nov 17 doi: 10.1136/vetreco-2019-000369.

[15] T. Tomazi, A.F. de Souza Filho, M.B. Heinemann, M.V. dos Santos, Molecular characterization and antimicrobial susceptibility pattern of streptococcus agalactiae isolated from clinical mastitis in dairy cattle PLoS ONE, 13 (6), 2018. doi: 10.1371/journal.pone.0199561

[16] Elsayed, M.S.A.E., T. Roshdey, A. Salah, G. Youni, D. Eldeep, Phenotypic and genotypic methods for identification of slime layer production, efflux pump activity, and antimicrobial resistance genes as potential causes of the antimicrobial resistance of some mastitis pathogens from farms in Menoufia, Egypt. Molecular Biology Reports. vol. 46, Issue 6. $1^{\text {st }}$ December 2019. Pages 6533-6546. DOI: 10.1007/s11033-019-05099-6.

[17] E. Kirsanova, B. Heringstad, A. Lewandowska-Sabat, I. Olsaker, Identification of candidate genes affecting chronic subclinical mastitis in Norwegian Red cattle: combining genome-wide association study, topologically associated domains and pathway enrichment analysis. Animal Genetics, 51(1), pp. 22-31, 2020.

[18] Ma, C., Zhao, J., Xi, X., Ding, J., Wang, H., Zhang, H., Kwok, L.Y. Bovine mastitis may be associated with the deprivation of gut Lactobacillus, Benef Microbes. 2016 Feb; 7(1) pp. 95-102, Epub 2015 Oct 9. doi: 10.3920/BM2015.0048.

[19] G. Oikonomou, Addis, MF, Chassard, C and et. Milk Microbiota: What Are We Exactly Talking About,. Frontiers in microbiology, 11, 2020 doi: 10.3389/fmicb.2020.00060

[20] Connie Mahon, Donald Lehman. Textbook of Diagnostic Microbiology. Page Count: 1088, 2018

[21] H. Derakhshani, Fehr, KB; Sepehri, S. Invited review: Microbiota of the bovine udder: Contributing factors and potential implications for udder health and mastitis susceptibility. Journal of dairy science, 12, 2018. doi:10.3168/jds.2018-14860

[22] Artur Burmanczuk, Kowalski, Cezary; Rolinski, Zbigniew and et. Activity of beta-lactam antibiotics against certain microorganisms which cause mastitis in cows Journal of veterinary research, 2016. doi: https://doi.org/10.1515/jvetres-2016-0041

\section{Creative Commons Attribution License 4.0 (Attribution 4.0 International, CC BY 4.0)}

This article is published under the terms of the Creative Commons Attribution License 4.0 https://creativecommons.org/licenses/by/4.0/deed.en US 